\title{
The missing limb: Including impacts of biomass extraction on forest carbon stocks in GHG balances of wood use
}

\author{
Horst Fehrenbach 1, Mascha Bischoff 1,2, Hannes Böttcher, Judith Reise and Klaus Josef Hennenberg 3,* \\ 1 ifeu - Institut für Energie- und Umweltforschung Heidelberg gGmbH, Wilckensstraße 3, 69120 Heidelberg \\ Germany; horst.fehrenbach@ifeu.de (H.F.) \\ 2 Environmental Research Institute, North Highland College, Castle Street, Thurso KW14 7JD, UK; mas- \\ cha.bischoff@uhi.ac.uk (M.B.) \\ 3 Öko-Institut e.V., Rheinstraße 95, 64295 Darmstadt, Germany; h.boettcher@oeko.de (H.B.); j.reise@oeko.de \\ (J.R.) \\ * Correspondence: k.hennenberg@oeko.de (K.J.H.); +49 6151-8191-177
}

\begin{abstract}
The global carbon neutrality challenge places a spotlight on forests as carbon sinks. However, greenhouse gas (GHG) balances of wood for material and energy use often reveal GHG emission savings in comparison with a non-wood reference. Is it thus better to increase wood production and use, or to conserve and expand the carbon stock in forests? GHG balances of wood products mostly ignore the dynamics of carbon storage in forests, which can be expressed as the carbon storage balance in forests (CSBF). For Germany, a CSBF of 0.25 to $1.15 \mathrm{t} \mathrm{CO}_{2} / \mathrm{m}^{3}$ wood can be assumed. When the CSBF is integrated into the GHG balance, GHG mitigation substantially deteriorates and wood products may even turn into a GHG source, e.g. in the case of energy wood. Here, building up the forest carbon sink would be the better option. We conclude that it is vital to include the CSBF in GHG balances of wood products if the wood is extracted from forests. Only then can GHG balances provide political decision-makers and stakeholders in the wood sector with a complete picture of GHG emissions.
\end{abstract}

Keywords: greenhouse gas balance; wood products; forest management; climate change mitigation; carbon storage;

\section{Introduction}

The Paris Agreement requires a substantial reduction of greenhouse gas (GHG) emissions in the coming decades and a balance of remaining GHG emissions with carbon sinks by the middle of this century. Forests and their ability to sequester carbon are expected to play a key role in reaching peak carbon emissions and achieving carbon neutrality. Consequently, different countries across the world are in the process of defining targets not only for their entire economy but also for carbon sinks in forests and other land uses. At the same time, countries struggle to implement consistent policies and measures to achieve these targets. A range of complex factors need to be taken into account to accurately assess which options, including forest management and wood use, are best suited to achieve ambitious mitigation targets in forests and the entire economy.

The European Commission (EC) has recently proposed nationally binding targets for the Land Use, Land-Use Change and Forestry (LULUCF) sector in their Member States (MS) for 2030 to achieve an EU-wide net sink target of $-310 \mathrm{Mt} \mathrm{CO}$ [1]. The target for Germany was set to $-30.8 \mathrm{Mt} \mathrm{CO}_{2}$. Similarly, the German Federal Government's Climate Protection Act requires a net sink in the LULUCF sector of $-25 \mathrm{Mt} \mathrm{CO}_{2} \mathrm{e}$ in 2030. According to Hennenberg et al. [2], this target requires a net sink in German forests of approx. $-35 \mathrm{Mt}$ $\mathrm{CO}_{2} \mathrm{e}$ in 2030. In comparison, the GHG inventory of the German government reports -57.0 $\mathrm{Mt} \mathrm{CO}_{2} \mathrm{e}$ for forests in 2019. However, these estimates may be based on incomplete assumptions. For instance, severe natural disturbances occurred in Germany between 2018 and 2020 due to drought and bark beetle calamities, which led to a significant decrease in 
forest vitality $[3,4]$. This resulted in a strong increase of salvage logging, which amounted to $75 \%$ of the entire annual wood removals in 2020 [5,6] [6]. These effects have not yet been included in the above-mentioned GHG inventory and it is to be expected that the sink performance will have to be corrected in subsequent GHG inventories. Furthermore, the net sink of forests is not only influenced by natural disturbances, but also by the intensity of forest management [7]. The comparison of forest management scenarios for the forest area in Germany also show that higher carbon storage can be achieved on the forest area with more extensive forest management [8-10]. Evidently, calculation targets and the planning of mitigation measures involving forests need to consider an intricate network of factors.

When it comes to GHG mitigation in practice, the question of the benefits and drawbacks of different options for mitigation measures arises. Is it better to increase wood production or to refrain from it to conserve or build up the forest carbon stock? This question cannot usually be addressed with a GHG inventory alone, since emissions arising along the process chain are reported in different sectors. The effect of material wood use on forests is assigned to the LULUCF sector, whereas emissions from harvesting occur in the agriculture sector and wood processing is considered in the industry sector. Transport is reported in the transport sector and possible substitution effects due to the displacement of fossil and mineral products such as heating oil or reinforced concrete may be relevant across all sectors. This clear sector allocation of GHG emissions is necessary to avoid double counting at country level [11]. However, to explore the environmental impacts of the use of wood products in comparison with alternative materials, a so-called life cycle assessment (LCA) approach is required. The LCA method or GHG balance [12,13] is suitable for determining GHG emissions and GHG savings along the process chain of wood products and comparing these with alternatives, e.g. fossil and mineral products. The results can be used by decision-makers and consumers to favor climate-friendly wood products over less climate-friendly options.

Several studies document that reductions of GHG emissions may be achieved with the material and energetic use of wood products [14-18]. The EU Renewable Energy Directive (RED II [19]) assumes a reduction of GHG emissions of over $80 \%$ in comparison with a fossil fuel reference when stem wood is used for energy purposes in the heating and cooling sector (transport distance $<2,500 \mathrm{~km}$ ). However, a common weakness in the GHG accounting of wood uses lies in the oversimplification of the balance of forest carbon stock. In fact, GHG balances of wood products commonly assume sustainable forest management as a default. Thus, the underlying assumption is that the amount of timber felled for a product grows back on neighboring areas simultaneously. Therefore, emissions from a forest caused by forest management and wood harvesting are expected to be net zero and effects from forest management are not further considered in the GHG balance (compare [20]). However, if harvesting is either reduced or increased, the storage capacity of the forest changes in response. Trees not harvested still store carbon and continue to grow and fix carbon in addition to the trees in neighboring areas. At the same time, tree mortality might change with changing tree density and tree age.

In light of the common neglect of the impacts of forest management practices, the aim of this paper is to integrate the carbon storage balance in forests (CSBF) into the GHG balance of wood use and to assess the relevance of the CSBF in a case study modelling GHG balances for wood use in Germany.

\section{Materials and Methods}

For the case study, GHG balances were calculated for six wood product groups, i.e. construction wood, chipboard and medium density fiberboard (MDF) for material use and wood chips, pellets and firewood for energy use. A temporal reference is required for the calculation of the carbon storage of wood products and - depending on the methodology - also for the CSBF. Since the overall objective is to reduce GHG emissions by 2050, 
the period from 2020 to 2050 (30 years) was defined as the credit period for the following calculations.

\subsection{Total GHG balance}

Looking at the normative specifications for LCA $[12,13]$ and carbon footprinting [21], it is undisputed that all GHG emissions directly arising from production and use phase shall be considered for GHG accounting of wood products. Furthermore, it is generally accepted that material use of wood not only stores carbon in the technosphere [22], but also that the substitution of non-wood products with wood products can achieve additional GHG savings [23,24]. The following factors are relevant for the total GHG balance of wood products (TBWP):

1. GHG emissions along the production chain of wood products (PCWP): all activities associated with wood production in the forest and for the manufacture of a specific product (including transport and use)

2. Carbon storage of wood products (CSWP): capacity for carbon storage in wood products

3. Carbon storage balance in forests (CSBF): changes in the carbon storage capacity of the forest in response to forest management and wood harvesting activities

4. Substitution effects (SE): substitution of non-wood products by wood products and a comparison of GHG emissions

The total GHG balance of wood products is calculated as:

$$
\mathrm{TBWP}=\mathrm{PCWP}+\mathrm{CSWP}+\mathrm{CSBF}+\mathrm{SE}
$$

The GHG emission reduction (ER) achieved by a wood product is calculated in relation to the substitution of non-wood products:

$$
\mathrm{ER}=(\mathrm{PCWP}+\mathrm{CSWP}+\mathrm{CSBF}) / \mathrm{SE}
$$

The following subchapters describe the assumptions made for these factors.

\subsection{GHG emissions along the production chain (PCWP)}

The calculation of total GHG emissions along the production chain for wood product groups was carried out using the HoLCA model based on Fehrenbach et al. [15] assuming mass-based allocation. In consequence, GHG emissions arising from a specific stage in the production process are allocated to main and by-products according to their respective mass. Sahoo et al. [25] show in their review of about 100 LCAs on forest-based products that the majority use the mass-based allocation approach. The only alternative is the market value-based approach that requires information for different wood qualities, including prices and wood share used as main or co-product. From our point of view, the massbased allocation has the advantage that it can be applied in a simple and transparent way.

MDF production is associated with high emissions due to the addition of synthetic resin. Please note that aggregation at product group level requires simplifications. At the end of the life cycle of wood products, a combination of recycling and energy recovery options are available. However, these result in new products with product life cycles, which in turn represent individual systems in an LCA and are not included in the GHG balance. The GHG emissions along the production chain are summarized in Table 1. 
Table 1. GHG emissions along the production chain of wood products (PCWP).

\begin{tabular}{|c|c|c|c|c|}
\hline \multirow[t]{2}{*}{ Use $^{1}$} & \multirow[t]{2}{*}{ Product } & $\begin{array}{l}\text { Wood input from } \\
\text { forests }{ }^{1}\end{array}$ & $\begin{array}{l}\text { Proportion of wood } \\
\text { in the product }\end{array}$ & $\begin{array}{l}\text { GHG emissions along the } \\
\text { production chain (PCWP) }\end{array}$ \\
\hline & & (kg woodair-dry/kg product) & & ( $\mathrm{kg} \mathrm{CO}_{2} / \mathrm{kg}$ product) \\
\hline \multirow{3}{*}{ Material } & Construction wood & 1.04 & 1.00 & 0.18 \\
\hline & Chipboard & 1.09 & 0.95 & 0.40 \\
\hline & $\mathrm{MDF}^{2}$ & 0.64 & 0.56 & 2.68 \\
\hline \multirow{3}{*}{ Energetic } & Wood chips & 1.00 & 1.00 & 0.04 \\
\hline & Pellets & 1.00 & 1.00 & 0.19 \\
\hline & Firewood & 1.00 & 1.00 & 0.07 \\
\hline
\end{tabular}

${ }^{1}$ The input volume corresponds to the physical material flow (allocation by mass). Values $>1$ imply material loss along the production chain (residual materials not used elsewhere); values $<1$ imply that the product contains non-wood components (e.g. MDF board with a high proportion of synthetic resin).

${ }^{2} \mathrm{MDF}=$ Medium density fiberboard.

Source: own calculations based on the HoLCA model using data from Fehrenbach et al. [15]

\subsection{Carbon storage capacity of wood products (CSWP)}

The mean carbon storage capacity of wood products was estimated based on data on carbon content and the proportion of wood in a product. For construction wood, we assume an average lifetime of 70 years, whereas the average lifetime for chipboard and MDF was 50 years [15]. Since the LCA models the period from 2020 to 2050 and the assumed life spans are longer than 30 years, the sequestered carbon of a product is fully accounted for in the GHG balance as a simplification. (Table 2). In case of products with a shorter lifetime only a share of the sequestered carbon should be accounted.

According to the German GHG inventory [26] and related Common Reporting Format (CRF) tables, an additional 4.73 million $\mathrm{m}^{3}$ of wood was added to the wood product storage of sawn wood and wood panel on average between 2010 and 2019 resulting in an additional mean storage of $-3.21 \mathrm{Mt} \mathrm{CO}$. This corresponds to $-0.74 \mathrm{t} \mathrm{CO}_{2} / \mathrm{m}^{3}$ or, with an average wood weight of $0.50 \mathrm{t} / \mathrm{m}^{3}$, to $-1.48 \mathrm{t} \mathrm{CO}_{2} / \mathrm{tair}_{\text {-dry }}$. This value falls within an order of magnitude comparable to the values for the carbon storage capacity of wood products in Table 2.

Table 2. Calculation of the mean carbon storage capacity of wood products (CSWP) during a credit period of 30 years (material use only).

\begin{tabular}{cccc}
\hline \multirow{2}{*}{ Product } & $\begin{array}{c}\text { Carbon content } \\
\text { of wood }[22]\end{array}$ & $\begin{array}{c}\text { Carbon storage capacity } \\
\text { of products }{ }^{1}\end{array}$ & $\begin{array}{c}\mathrm{CO}_{2} \text { storage capacity } \\
\text { of products (CSWP) }{ }^{2}\end{array}$ \\
\cline { 2 - 4 }$(\mathrm{kg} \mathrm{C} / \mathrm{kg}$ woodair-dry & $(\mathrm{kg} \mathrm{C} / \mathrm{kg} \mathrm{product})$ & $\left(\mathrm{kg} \mathrm{CO}_{2} / \mathrm{kg} \mathrm{product}\right)$ \\
\hline Construction wood & 0.50 & -0.50 & -1.83 \\
\hline Chipboard & 0.50 & -0.48 & -1.74 \\
\hline MDF $^{3}$ & 0.50 & -0.28 & -1.03 \\
\hline
\end{tabular}

${ }^{1}$ Calculation: (carbon content of wood) ${ }^{*}$ (proportion of wood in the product; Table 1$){ }^{*}(-1)$.

${ }^{2}$ Stoichiometric conversion from $\mathrm{C}$ to $\mathrm{CO}_{2}$ (factor 44/12).

${ }^{3} \mathrm{MDF}=$ Medium density fiberboard.

\subsection{Carbon storage balance in forests (CSBF)}

The German GHG Inventory [26] derives emission factors for changes in biomass carbon stocks, i.e. living biomass, of forests from national forest inventories and calibrates them on the basis of the annual quantity of logged wood following the method provided by Röhling et al. [7].

In the period from 2008 to 2017 (Figure 1), between 64.5 and $76.1 \mathrm{Mm}^{3}$ of wood (6.0 to $7.3 \mathrm{~m}^{3} / \mathrm{ha}$ ) were harvested. This corresponded to a carbon storage capacity of the living 
biomass on the forest area of -43.1 to $-50.2 \mathrm{Mt} \mathrm{CO}_{2}\left(-3.8\right.$ to $\left.-4.7 \mathrm{t} \mathrm{CO}_{2} / \mathrm{ha}\right)$. The CSBF expressed as ton $\mathrm{CO}_{2}$ per cubic meter of harvested wood amounts to $-0,62$ t $\mathrm{CO}_{2} / \mathrm{m}^{3}$ (see regression in Figure 1). This means that harvesting decreases the carbon storage capacity of living biomass by this factor, whereas carbon storage capacity increases by the same factor when harvesting is reduced.

The years 2002 to 2007 (Figure 1) were a period of strong natural disturbances, i.e. two storms (2002 storm "Janette", 2007 storm "Kyrill") and a drought in 2003. The resulting damage led to a general decrease of the carbon storage capacity of the living biomass in forests between $-12,6$ to $-22,5 \mathrm{Mt} \mathrm{CO}$ ( $(-1,2$ to $-2,1$ t CO $2 /$ ha), which was considerably lower than the storage capacity between 2008 and 2017. The CSBF also declined to a value of $0.25 \mathrm{t} \mathrm{CO}_{2} / \mathrm{m}^{3}$ (see regression in Figure 1), as not only harvesting but also increased natural mortality rates impact the carbon storage capacity of living biomass.

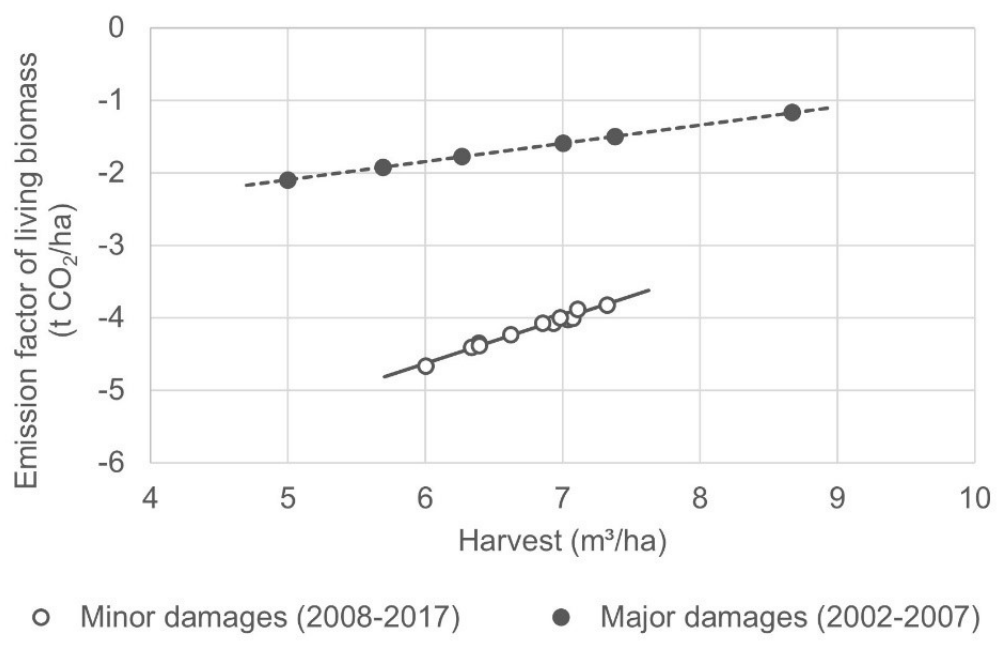

Figure 1. Relation between the emission factor of living biomass in German forests and wood harvest for a period with major storm and drought damage (dotted line, $y=-0,253 \mathrm{x}+3,363 ; \mathrm{r}^{2}=1,000$ ) and for a period with minor damage (solid line, $\left.y=-0,620 x+8,353 ; r^{2}=0,984\right)$. Source: Emission factor of living biomass from CRF-tables adopted from [26], harvest rate adopted from [6].

The CSBF can also be determined assuming two forest management scenarios with different levels of use intensity (e.g. current use versus no use). The difference in carbon stored on the forest area per scenario and the difference in the amount of wood harvested are compared. Based on the analysis of several studies modelling forests in Germany, the CSBF ranges from 0.62 to $1.68 \mathrm{t} \mathrm{CO}_{2} / \mathrm{m}^{3}$ with a mean of $1,15 \mathrm{t} \mathrm{CO}_{2} / \mathrm{m}^{3}$ (see [27] and detailed data in [28]).

Based on the data and results presented above, we assumed four different levels for the CSBF (no-CSBF, low-CSBF, med-CSBF and high-CSBF; see description in Table 3). These levels are used for scenarios in a sensitivity analysis of the total GHG balance. For each wood product, the respective CSBF is multiplied by the wood input from forests (see calculation in Table 4). 
Table 3. Carbon storage balance in forests (CSBF) for removed wood.

\begin{tabular}{|c|c|c|c|c|}
\hline \multirow{2}{*}{ Level } & \multicolumn{3}{|c|}{ Carbon storage balance in forests (CSBF) } & \multirow{2}{*}{ Note } \\
\hline & $\left(\mathrm{t} \mathrm{CO}_{2} / \mathrm{m}^{3}\right)$ & $\left(\mathrm{t} \mathrm{CO}_{2} / \mathrm{t}_{\text {air-dry }}\right)^{1}$ & $\left(\mathrm{~g} \mathrm{CO}_{2} / \mathrm{MJ}\right)^{2}$ & \\
\hline no-CSBF & 0.00 & 0.00 & 0.00 & $\begin{array}{l}\text { No CSBF: CSBF is not taken into account. This reflects the } \\
\text { assumption that the removal of the wood has no effect on } \\
\text { the development of the carbon stock in the forest. }\end{array}$ \\
\hline low-CSBF & 0.25 & 0.32 & 21.3 & $\begin{array}{l}\text { Low CSBF: Lower threshold of the CSBF according to } \\
\text { data reported in [26] and [6], see Figure } 1\end{array}$ \\
\hline med-CSBF & 0.62 & 0.79 & 52.7 & $\begin{array}{l}\text { Medium CSBF: Upper threshold of the CSBF according to } \\
\text { data reported in [26] and [6], see Figure } 1\end{array}$ \\
\hline high-CSBF & 1.15 & 1.46 & 97.3 & $\begin{array}{l}\text { High CSBF: Higher threshold of the range of the CSBF } \\
\text { according to modelling results (period: 2020-2050) [27] } \\
\text { [28]) }\end{array}$ \\
\hline
\end{tabular}

${ }^{1}$ Mean wood density of 0,79 tair-dry $/ \mathrm{m}^{3}$ [29]

${ }^{2}$ Heating value of $15 \mathrm{MJ} / \mathrm{kg}_{\text {air-dry }}[15]$

Table 4. Carbon storage balance in forests for individual groups of wood products.

\begin{tabular}{|c|c|c|c|c|c|}
\hline \multirow{2}{*}{ Use $^{2}$} & \multirow{2}{*}{ Product } & No-CSBF 1 & Low-CSBF 1 & Med-CSBF ${ }^{1}$ & High-CSBF \\
\hline & & \multicolumn{4}{|c|}{$\left(\mathrm{kg} \mathrm{CO}_{2} / \mathrm{kg}\right.$ product $)$} \\
\hline \multirow{3}{*}{ Material } & Construction wood & 0,00 & 0,33 & 0,82 & 1,52 \\
\hline & Chipboard & 0,00 & 0,35 & 0,86 & 1,59 \\
\hline & $\mathrm{MDF}^{2}$ & 0,00 & 0,20 & 0,51 & 0,93 \\
\hline \multirow{3}{*}{ Energetic } & Wood chips & 0,00 & 0,32 & 0,79 & 1,46 \\
\hline & Pellets & 0,00 & 0,32 & 0,79 & 1,46 \\
\hline & Firewood & 0,00 & 0,32 & 0,79 & 1,46 \\
\hline
\end{tabular}

${ }^{1}$ Calculation: (carbon storage balance in forests (CSBF), Figure 3$){ }^{*}$ (wood input from forests; Table 1)

${ }^{2} \mathrm{MDF}=$ Medium density fiberboard.

\subsection{Substitution effects}

Substitution effects occur when a non-wood product is replaced by a wood product with the same degree of functionality. If the GHG emissions of the wood product are lower than those of the non-wood product, a GHG reduction is achieved. Table 5 presents expected substitutes and substituted GHG emissions for the wood product groups construction wood, chipboard, MDF and energy wood (wood chips, pellets, firewood). 
Table 5. Potential substitution effects of wood products.

\begin{tabular}{|c|c|c|c|c|c|}
\hline \multicolumn{6}{|c|}{ Material use } \\
\hline \multirow{2}{*}{$\begin{array}{l}\text { Wood } \\
\text { product }\end{array}$} & \multirow{2}{*}{ Substitute } & $\begin{array}{c}\text { Proportion } \\
{[15]} \\
\end{array}$ & $\begin{array}{c}\text { Substitution } \\
\text { Factor [15] }\end{array}$ & $\begin{array}{c}\text { GHG emissions } \\
\text { substitute [15] }\end{array}$ & $\begin{array}{l}\text { Substitution } \\
\text { effect }(S P)^{1}\end{array}$ \\
\hline & & & $\begin{array}{c}\text { (kg substitute/ } \\
\text { kg wood product) }\end{array}$ & $\begin{array}{c}(\mathrm{kg} \mathrm{CO} / \\
\text { kg substitute) }\end{array}$ & $\begin{array}{c}(\mathrm{kg} \mathrm{CO} / \\
\mathrm{kg} \text { wood product })\end{array}$ \\
\hline \multirow{3}{*}{$\begin{array}{l}\text { Construc- } \\
\text { tion wood }\end{array}$} & Steel & 0.50 & 2.00 & 1.72 & -1.72 \\
\hline & Concrete & 0.50 & 4.80 & 0.125 & -0.30 \\
\hline & Weighted total & & & & -2.02 \\
\hline \multirow{4}{*}{ Chipboard } & Plasterboard & 0.50 & 0.80 & 0.34 & -0.14 \\
\hline & Steel sheets & 0.40 & 1.20 & 1.72 & -0.83 \\
\hline & $\begin{array}{c}\text { Lightweight concrete } \\
\text { elements }\end{array}$ & 0.10 & 8.00 & 1.17 & -0.94 \\
\hline & Weighted total & & & & -1.87 \\
\hline $\mathrm{MDF}^{3}$ & Plastic (PVC) & 1.00 & 1.0 & $1.56^{2}$ & -1.56 \\
\hline
\end{tabular}

Energy use

\begin{tabular}{cccccc}
\hline \multirow{2}{*}{$\begin{array}{c}\text { Wood } \\
\text { product }\end{array}$} & Substitute & $\begin{array}{c}\text { Proportion } \\
{[19]}\end{array}$ & $\begin{array}{c}\text { Substitution } \\
\text { Factor [19] }\end{array}$ & $\begin{array}{c}\text { GHG emissions } \\
\text { substitute [19] }\end{array}$ & $\begin{array}{c}\text { Substitution } \\
\text { effect (SP) }\end{array}$ \\
\cline { 3 - 6 } & & $\begin{array}{c}\text { (MJ substitute/ } \\
\text { MJ wood product) }\end{array}$ & $\begin{array}{c}\mathrm{g} \mathrm{CO}_{2} / \\
\text { MJ substitute }\end{array}$ & $\begin{array}{c}(\mathrm{kg} \mathrm{CO} / \\
\text { kg wood product) }\end{array}$ \\
\hline $\begin{array}{l}\text { Energy } \\
\text { wood }^{5}\end{array}$ & Fossil fuel mix & 1.0 & 1.0 & 80.0 & $-1.20^{4}$ \\
\hline
\end{tabular}

${ }^{1}$ Calculation: (proportion) ${ }^{*}$ (substitution factor) ${ }^{*}($ GHG emissions substitute $) *(-1)$.

2 Own estimation.

${ }^{3} \mathrm{MDF}=$ Medium density fiberboard.

${ }^{4}$ Calculation: (proportion) * (substitution factor) * (GHG emissions substitute) * (heating value of $15 \mathrm{MJ} / \mathrm{kg}$ air-dry [15] * (-1).

${ }^{5}$ Energy wood $=$ wood chips, pellets, and firewood.

\section{Results}

The total GHG balances and the GHG emission reduction per wood product group are presented in Figure 2 and Figure 3, assuming four different levels for the CSBF (noCSBF, low-CSBF, med-CSBF and high-CSBF scenario; see description in Table 1). In the no-CSBF scenario, a GHG reduction is achieved with most wood products (Figure 2) and the GHG reduction shows values above $155 \%$ for construction wood and chipboard and above $85 \%$ for energy wood. Substitution effects play a major role and the carbon storage of wood products is equally important. The exception is MDF due to high emissions from the fossil addition, thus no GHG reduction is achieved in the no-CSBF scenario. With increasing CSBF, the GHG balance of all wood products decreases significantly (Figure 2). If a high value for the CSBF (high-CSBF scenario) is included in the calculation, the GHG balance deteriorates so much that energy wood turns into a GHG source. However, construction wood and chipboard can still reduce GHG emissions compared to the non-wood reference (Figure 2). It is remarkable that the GHG emission savings for energy wood already decline below 70\%, a threshold set in RED II [19], in the low-CSBF scenario and reach below $0 \%$ in the high-CSBF scenario (Figure 3). 


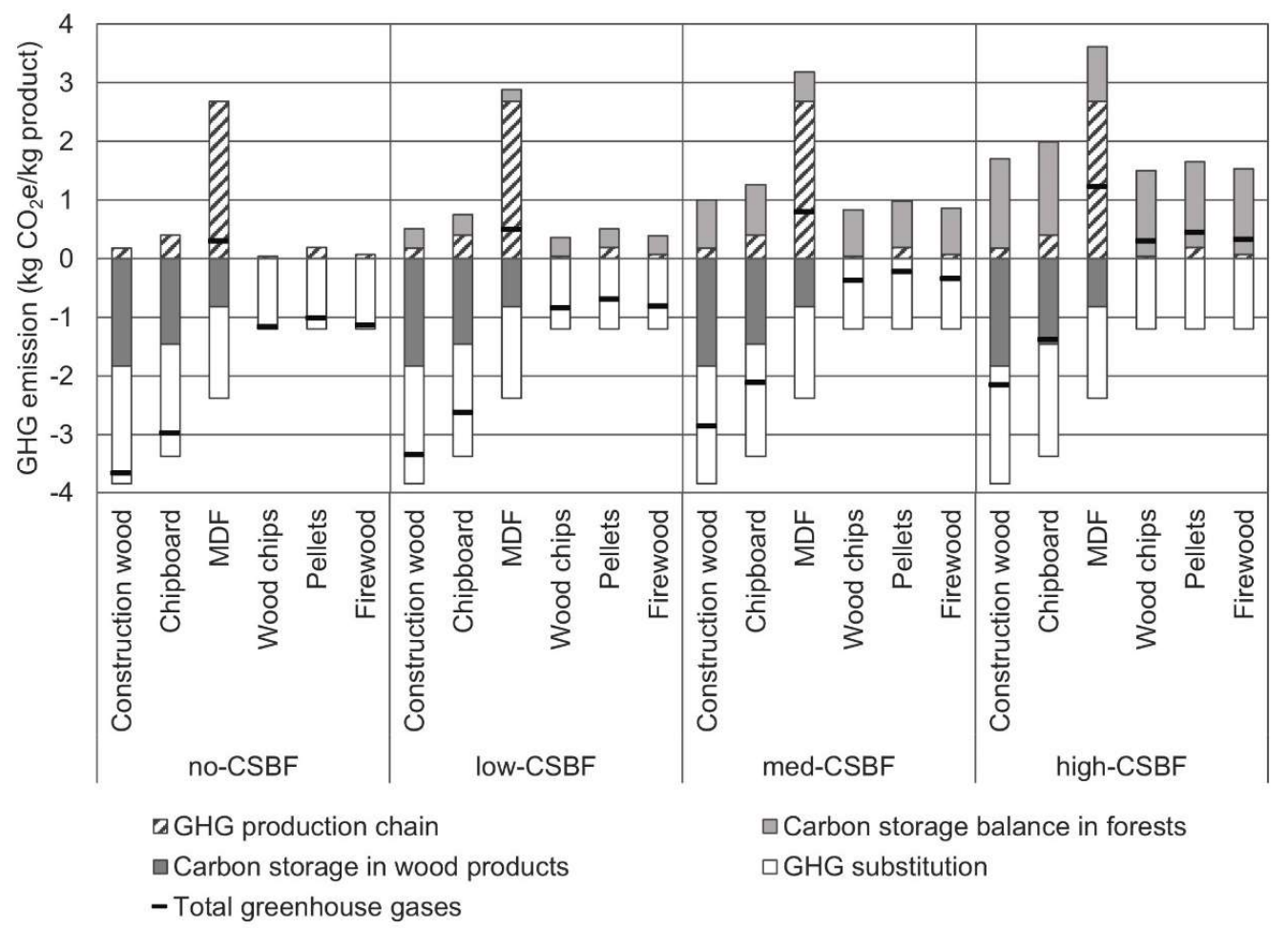

Figure 2. Greenhouse gas balances of wood products in different carbon storage balance scenarios in forests. MDF $=$ medium-density fiberboard, CSBF = carbon storage balance in forests. See explanation of the scenarios no-CSBF, low-CSBF, med-CSBF and high-CSBF in Table 3.

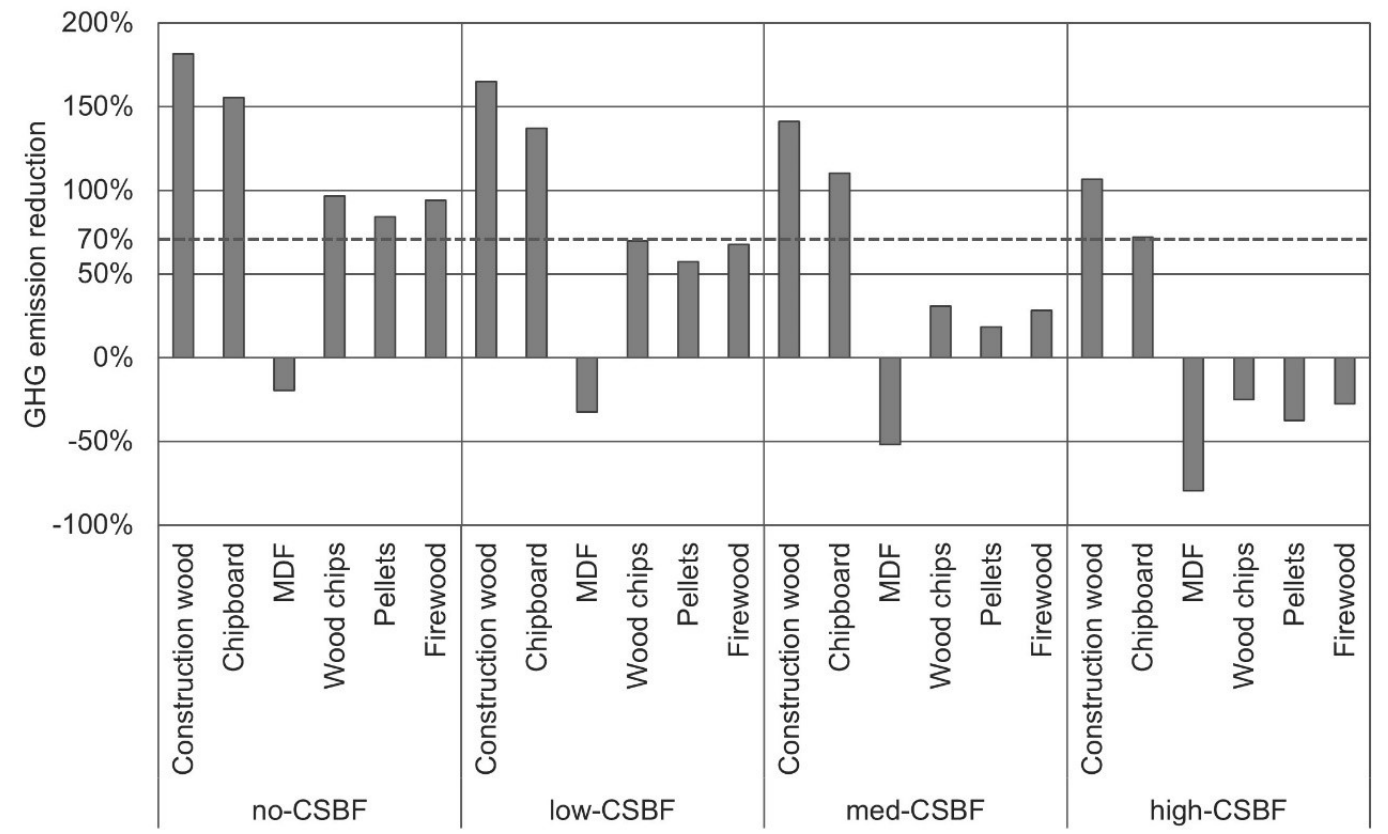

Figure 3. Greenhouse gas reduction of wood products in relation to non-wood products in different carbon storage balance scenarios in forests. MDF = medium-density fiberboard, $\mathrm{CSBF}=$ carbon storage balance in forests. See explanation of the scenarios no-CSBF, low-CSBF, med-CSBF and high-CSBF in Table 3. 


\section{Discussion}

In this study, we propose an approach to consider changes in forest carbon stock in GHG balances of wood products. Our method is designed to comply with the ISO requirements for both LCA [12,13] and carbon footprint calculation [21]. This is achieved by reporting the CSBF as a parameter quantifying $\mathrm{CO}_{2}$ emissions per harvested volume of wood, and can thus be incorporated into the material flow framework of the GHG balance. Reductions of GHG emissions associated with a wood product in comparison with a fossil or mineral reference are determined with comparative LCA.

The GHG balances calculated here show as a clear pattern. With long-life wood products such as construction wood and chipboard, substantial GHG reductions can be achieved compared to the non-wood reference. In contrast, the GHG reductions for energy wood are considerably lower. The difference between these two product groups arises from two factors: first, a significant amount of carbon is stored in long-lived wood products, and second, the achievable substitution effects are higher for long-lived wood products than for energy wood (see [30,31]). In the GHG balance, MDF performs particularly poorly due to the high amount of fossil additives. This illustrates that long-life wood products do not per se contribute to climate protection. Our results for GHG emissions arising from the process chain, $\mathrm{CO}_{2}$ storage in wood products, and avoidance of emissions by substitution with non-wood products - excluding the CSBF - are of the same order of magnitude as in other studies on the use of wood products in Germany [15,23,32]. In these studies, substitution effects also play a significant role in improving the GHG balance of wood products.

Please note that substitution is not an inherent part of the wood use system. Unlike the other components of the total GHG balance, material substitution extends into other product systems. Although disaggregation of all individual components of the total GHG balance is always required for reasons of transparency, this is especially true for substitution. Modelling substitution involves an additional full LCA. It also requires assumptions and analyses of market events and adopts potential scenarios that cannot be clearly defined. Evidently, the choice of which particular metal or plastic replaces a wooden table is highly dependent on assumptions. However, if wood use cannot guarantee that nonwood products associated with high GHG emissions are substituted, the GHG balance will deteriorate accordingly [33]. In contrast, the CSBF is an inherent part of wood production and must be considered in the LCA of wood products. The comparative LCA we carried out is transparent and includes all relevant details. It allows researchers to integrate the results including the CSBF in future studies and to replace substitutes where required.

Similar approaches have been developed in recent years [34-36], comparing forest scenarios with different harvest intensities with a focus on effects on the country level, as opposed to the product level. Pingoud et al. [34] introduced a relative carbon indicator that is most similar to CSBF. However, both the concept of payback time (e.g. $[20,37,38])$ and the concept of the displacement factor (synonym substitution factor; $[39,40]$ ) conflate the individual GHG balances of a wood product and a non-wood product into one indicator. As a result, there is a loss of transparency. The respective shares of wood and nonwood products in the GHG balance are no longer apparent. Consequently, the subsequent use of results, e.g. in other studies, is more complicated. The so-called payback time calculates the required time period until forest regrowth and reduction in fossil emissions can jointly pay back the carbon debt on the first stand harvested. Thus, the results of a comparative GHG balance, which always includes changes in the sink performance of the forest area, are expressed as a time period. The displacement factor compares the GHG balance of wood and non-wood products and correlates the result to the wood used. In their recent review on the concept, Myllyviita et al. [40] noted that very few studies included changes in forest and product carbon stocks in displacement factors. This finding highlights that the CSBF is currently mostly ignored in studies, yet also confirms that its integration into the displacement factor is possible. 
The debate on the CSBF and payback time is not purely academic, is has a political dimension. At present, the IEA assumes that despite changes in the forest sink, e.g. the use of firewood is compatible with the goals of the Paris Agreement [41]. This is called into question by the European Academies Science Advisory Council (EASAC), which assumes considerably longer carbon payback times [42]. Our findings for wood products in Germany, however, show that the consideration of the CSBF has a marked influence on the GHG balance of wood products. For instance, the GHG emission savings from chipboard and construction wood decrease from $155 \%$ and $180 \%$, respectively, without CSBF to savings of $70 \%$ and $105 \%$, respectively, when a high CSBF is assumed. In consequence, reliable, albeit reduced, GHG emission savings can be expected for long-life wood products when the CSBF is considered. However, the picture changes for wood energy. Without considering the CSBF, the GHG emission savings amount 85 to $95 \%$. However, with a high CSBF, no GHG reduction can be achieved compared to non-wood reference. Even at a low CSBF, the GHG reduction dips below 70\%. In the RED II [19], the sustainability requirement stipulates that wood energy in new plants should achieve GHG emission savings of at least 70\% from 2021 and $80 \%$ from 2026. For wood pellets from stem wood, the RED II Annex gives default values of GHG savings for heat and electricity exceeding $70 \%$ compared to the fossil reference (transport distance up to $10.000 \mathrm{~km}$, process energy from wood chips). However, when the CSBF is considered, the GHG reduction does no longer meet the mandatory savings target. In their literature review, Agostini et al. [20] also highlight that temperate and boreal stemwood energy dedicated harvests achieve GHG savings only after 50 years compared to coal, and even later compared to natural gas (see also [38]). For harvest residues and thinning wood, however, GHG savings can be expected after 10 years [20,43]. Adopting a German perspective, Bolte et al. [44] point out that stock depletion, such as in the case of intensive energy use of wood, is detrimental to the climate, since the medium- and long-term reduction of the carbon sink in the forest can no longer be compensated by the substitution effects.

Similar to energy wood, other wood products with a short life cycle such as packaging wood or paper and cardboard can be expected to yield only low or no GHG emission savings if the CSBF is included. These products are generally associated with few GHG emission savings even before the CSBF is taken into account [15-18]. However, here lies the challenge of defining the non-wood reference, which should be addressed in future studies.

\section{Conclusions}

In light of our results, it is vital to include the CSBF in the GHG balances of wood products if the wood is extracted from forests. Only then can GHG balances give a complete picture of GHG emissions from wood products and provide political decision-makers and stakeholders in the wood sector with a reliable database for forest management, wood use and climate change mitigation.

As a general pattern, we demonstrate that GHG emission savings can be reliably achieved with long-life products even when the CSBF is taken into account, unless the GHG balance deteriorates due to the addition of fossil components with high GHG emissions. However, this is not reliably the case for wood energy and probably also for wood products with a short life cycle. As a consequence, the GHG perspective suggests that wood assortments primarily used for wood energy or short-lived wood products should not be harvested or harvest should be postponed to a later date to build up the carbon stock in the forest. However, it must also be taken into account that an increased wood stock must also be permanently maintained, such as in climate-resilient mixed deciduous forests $[45,46]$. These forest stands in particular provide additional benefits, e.g. increased habitat for rare and endangered species, when they increase in stock and mature [47-49]. Positive effects for the water balance and soil protection are also expected [50,51]. 
To optimize the interplay between forest sink performance and GHG emission reduction achieved with the use of wood products, the following key aspects should be considered.

- In climate-resilient forest stands with high ecological integrity (e.g. mainly deciduous and mixed forests in Germany) where mainly low-quality and short-lived wood products are expected, harvesting should be reduced to build up carbon stock.

- In forest stands with poor climate resilience and low ecological integrity (e.g. spruce forest in unsuitable locations in Germany), harvesting should continue with the longterm goal of conversion into climate-resilient forests.

- In forests where wood output is primarily used for high-value and long-life purposes, stock accumulation should not be the focus of the management strategy.

- Synergies and trade-offs with other ecosystem services such as biodiversity, soil, and water should be factored into decision-making.

In light of the challenges associated with the commitments of the Paris Agreement, the GHG balance approach for a more complete modelling of wood use presented here may provide a tool to support informed decisions of policy makers and other stakeholders in the overarching goal of sustainable climate change mitigation.

Author Contributions: H.F., K.J.H. and H.B. designed the approach; H.F., K.J.H. and M.B. conducted LCA; J.R. and K.J.H. visualized the results. All authors have read and agreed to the published version of the manuscript.

Funding: The research leading to results presented in this paper was funded by the German Ministry of Environment, grant number FKZ: 67KE0059.

Institutional Review Board Statement: Not applicable.

Informed Consent Statement: Not applicable.

Data Availability Statement: The data presented in this study are available on request from the corresponding author.

Conflicts of Interest: The authors declare no conflict of interest. The funders had no role in the design of the study; in the collection, analyses, or interpretation of data; in the writing of the manuscript, or in the decision to publish the results.

\section{References}

1. European Commission. Proposal for a Regulation of the European Parliament and of the Council Amending Regulations (EU) 2018/841 as Regards the Scope, Simplifying the Compliance Rules, Setting out the Targets of the Member States for 2030 and Committing to the Collective Achievement of Climate Neutrality by 2035 in the Land Use, Forestry and Agriculture Sector, and (EU) 2018/1999 as Regards Improvement in Monitoring, Reporting, Tracking of Progress and Review. Brussels, 14.7.2021. COM(2021) 554 final ANNEX. Available online: https://eurlex.europa.eu/resource.html?uri=cellar:ea67fbc9-e4ec-11eb-a1a5-01aa75ed71a1.0001.02/DOC 2\&format=PDF (accessed on 27 December 2021).

2. Hennenberg, K.; Boettcher, H.; Reise, J.; Herold, A.; Bohn, F.; Gutsch, M.; Reyer, C. Interpretation des Klimaschutzgesetzes für die Waldbewirtschaftung verlangt adäquate Datenbasis - Reaktion auf die Stellungnahme des Wissenschaftlichen Beirats für Waldpolitik beim BMEL (vom 22.06.2021). Öko-Institut Working Paper 2021, 1-28. https://www.oeko.de/fileadmin/oekodoc/03-WP-Klimaschutzgesetz-Waldbewirtschaftung.pdf (accessed on 27 December 2021)

3. BMEL Ergebnisse der Waldzustandserhebung 2020; Bundesministerium für Ernährung und Landwirtschaft (BMEL): Bonn, 2021; pp. 1-72. https://www.bmel.de/SharedDocs/Downloads/DE/Broschueren/ergebnissewaldzustandserhebung-2020.pdf? blob=publicationFile\&v=8 (accessed on 27 December 2021)

4. Ibisch, P.; Gohr, C.; Mann, D.; Blumröder, J. Der Wald in Deutschland auf dem Weg in die Heißzeit. Vitalität, Schädigung und Erwärmung in den Extremsommern 2018-2020.; Centre for Econics and Ecosystem Management Hochschule für nachhaltige $\quad$ Entwicklung $\quad$ Eberswalde: $\quad$ Eberswalde, $\quad 2021 ; \quad$ pp. 
https://www.researchgate.net/publication/356443090 Der Wald in Deutschland auf dem Weg in die Heissz eit Vitalitat Schadigung und Erwarmung in den Extremsommern 2018-2020 (accessed on 27 December 2021)

5. DESTATIS 41261-0003: Schadholzeinschlag: Deutschland, Jahre, Einschlagsursache, Holzartengruppen, Waldeigentumsarten. 2011 - 2020.; Statistisches Bundesamt (Destatis): Wiesbaden, 2021; https://wwwgenesis.destatis.de/genesis//online?operation=table\&code $=41261$ -

0003\&bypass=true\&levelindex=1\&levelid=1640635855139\#abreadcrumb (accessed on 27 December 2021)

6. Jochem, D.; Weimar, H.; Dieter, M. Holzeinschlag kalamitätsbedingt weiter angestiegen. Holz-Zentralblatt 2021, 147, 563-564. https://literatur.thuenen.de/digbib extern/dn063967.pdf (accessed on 27 December 2021)

7. Röhling, S.; Dunger, K.; Kändler, G.; Klatt, S.; Riedel, T.; Stümer, W.; Brötz, J. Comparison of Calculation Methods for Estimating Annual Carbon Stock Change in German Forests under Forest Management in the German Greenhouse Gas Inventory. Carbon Balance and Management 2016, 11, 12, doi:10.1186/s13021-016-0053-x.

8. Böttcher, H.; Hennenberg, K.; Winger, C. Forest Vision Germany. Waldvision Deutschland. Description of Methodology, Assumptions and Results.; Oeko-Institute: Freiburg. Berlin. Darmstadt, 2018 ; pp. 1-77. https://www.oeko.de/fileadmin/oekodoc/Forest-Vision-Methods-and-Results.pdf (accessed on 27 December 2021)

9. Gutsch, M.; Lasch-Born, P.; Kollas, C.; Suckow, F.; Reyer, C.P.O. Balancing Trade-Offs between Ecosystem Services in Germany's Forests under Climate Change. Environ. Res. Lett. 2018, 13, 045012, doi:10.1088/1748-9326/aab4e5.

10. Oehmichen, K.; Klatt, S.; Gerber, K.; Polley, H.; Röhling, S.; Dunger, K. Die alternativen WEHAM-Szenarien: Holzpräferenz, Naturschutzpräferenz und Trendfortschreibung - Szenarienentwicklung, Ergebnisse und Analyse; Thünen Report 59. Johann Heinrich von Thünen-Institut: DE, 2018; pp. 1-91. https://iteratur.thuenen.de/digbib extern/dn059875.pdf (accessed on 27 December 2021)

11. IPCC. 2006 IPCC Guidelines for National Greenhouse Gas Inventories. Prepared by the National Greenhouse Gas Inventories Programme. Edited by Eggleston H.S., Buendia L., Miwa K., Ngara T. and Tanabe K.; Intergovernmental Panel on Climate Change: Japan, 2006; Vol. 1; ISBN 4-88788-032-4.

12. ISO. ISO 14040:2006. Environmental Management-Life Cycle Assessment-Principles and Framework; International Organisation for Standardization: Geneva, Switzerland, 2006; pp. 1-20;

13. ISO. ISO 14044:2006. Environmental Management - Life Cycle Assessment - Requirements and Guidelines; International Organisation for Standardization: Geneva, Switzerland, 2006; pp. 1-46;

14. IPCC. Climate Change and Land: An IPCC Special Report on Climate Change, Desertification, Land Degradation, Sustainable Land Management, Food Security, and Greenhouse Gas Fluxes in Terrestrial Ecosystems; Intergovernmental Panel on Climate Change: Geneva, Switzerland, 2019; https:/www.ipcc.ch/site/assets/uploads/2019/11/SRCCLFull-Report-Compiled-191128.pdf (accessed on 27 December 2021)

15. Fehrenbach, H.; Köppen, S.; Kauertz, B.; Wellenreuther, F.; Baur, F.; Wern, B.; Breitmayer, E. Biomassekaskaden Mehr Ressourceneffizienz durch stoffliche Kaskadennutzung von Biomasse - von der Theorie zur Praxis - Gesamtökologische Betrachtung ausgewählter Biomassekaskaden; UBA Texte 53/2017; Umweltbundesamt: Dessau-Roßlau, 2017; pp. 1112. $\quad$ https://www.umweltbundesamt.de/sites/default/files/medien/1410/publikationen/2017-06-13 texte 532017 biokaskaden_anlage.pdf (accessed on 27 December 2021)

16. Höglmeier, K.; Steubing, B.; Weber-Blaschke, G.; Richter, K. LCA-Based Optimization of Wood Utilization under Special Consideration of a Cascading Use of Wood. J Environ Manage 2015, 152, 158-170, doi:10.1016/j.jenvman.2015.01.018.

17. Sathre, R.; González-García, S. Life Cycle Assessment (LCA) of Wood-Based Building Materials. In Eco-efficient Construction and Building Materials; Woodhead Publishing Limited, 2014; pp. 311-337 ISBN 978-0-85709-767-5. https://linkinghub.elsevier.com/retrieve/pii/B9780857097675500145 (accessed 27 December 2021)

18. Helin, T.; Holma, A.; Soimakallio, S. Is Land Use Impact Assessment in LCA Applicable for Forest Biomass Value Chains? Findings from Comparison of Use of Scandinavian Wood, Agro-Biomass and Peat for Energy. The International Journal of Life Cycle Assessment 2014, 19, 770-785, doi:10.1007/s11367-014-0706-5.

19. European Commission. Directive (EU) 2018/2001 of the European Parliament and of the Council of 11 December 2018 on the Promotion of the Use of Energy from Renewable Sources (Text with EEA Relevance.) Available online: https://eur-lex.europa.eu/eli/dir/2018/2001/oj (accessed on 23 December 2021).

20. Agostini, A.; Giuntoli, J.; Boulamanti, A.; Marelli, L. Carbon Accounting of Forest Bioenergy. Conclusions and Recommendations from a Critical Literature Review.; European Commission. Joint Research Centre. Institute for Energy and Transport.: Luxembourg, 2014; pp. 1-88; doi:10.2788/29442

21. ISO. ISO 14067:2018. Greenhouse Gases - Carbon Footprint of Products - Requirements and Guidelines for Quantification; International Organisation for Standardization: Geneva, Switzerland, 2018; pp. 1-46;. 
22. IPCC. Chapter 12: Harvested Wood Products. In Guidelines for National Greenhouse Gas Inventories, Volume 4: Agriculture, Forestry and Other Land Use; Intergovernmental Panel on Climate Change, 2006. https://www.ipccnggip.iges.or.jp/public/2006gl/pdf/4 Volume4/V4 12 Ch12 HWP.pdf (accessed on 27 December 2021)

23. Rüter, S.; Werner, F.; Forsell, N.; Prins, C.; Vial, E.; Levet, A. ClimWood2030, Climate Benefits of Material Substitution by Forest Biomass and Harvested Wood Products: Perspective 2030 - Final Report; Thünen Report 42; Johann Heinrich von Thünen-Institut: Braunschweig, 2016; ISBN 978-3-86576-160-6. https://literatur.thuenen.de/digbib extern/dn056927.pdf (accessed on 27 December 2021)

24. Leskinen, P.; Cardellini, G.; González-García, S.; Hurmekoski, E.; Sathre, R.; Seppälä, J.; Smyth, C.; Stern, T.; Verkerk, P.J.; European Forest Institute Substitution Effects of Wood-Based Products in Climate Change Mitigation; From Science to Policy; European Forest Institute, 2018; Vol. 7; ISBN 978-952-5980-70-7. DOI: https://doi.org/10.36333/fs07. https://efi.int/sites/default/files/files/publication-bank/2019/efi fstp 7 2018.pdf (accessed on 27 December 2021)

25. Sahoo, K.; Bergman, R.; Alanya-Rosenbaum, S.; Gu, H.; Liang, S. Life Cycle Assessment of Forest-Based Products: A Review. Sustainability. 11(17). 30 p. 2019, 11, doi:10.3390/su11174722.

26. Strogies, M.; Gniffke, P. Submission under the United Nations Framework Convention on Climate Change and the Kyoto Protocol 2021. National Inventory Report for the German Greenhouse Gas Inventory 1990 - 2019.; CLIMATE CHANGE 44/2021. Umweltbundesamt: Dessau-Roßlau, 2021; pp. 1-994. https://www.umweltbundesamt.de/sites/default/files/medien/5750/publikationen/2021-05-19 cc 442021_nir_2021_0.pdf (accessed on 27 December 2021)

27. Hennenberg, K.; Boettcher, H.; Wiegmann, K.; Reise, J.; Fehrenbach, H. Kohlenstoffspeicherung in Wald Und Holzprodukten. AFZ - Der Wald 2019, 17/2019, 36-39. speichersaldo.de/media/Hennenberg Oekobilanz sl.pdf (accessed on 27 December 2021)

28. Öko-Institut CO2-Speichersaldo Available online: https://co2-speichersaldo.de/ (accessed on 27 December 2021).

29. Döring, P.; Weimar, H.; Mantau, U. Einsatz von Holz in Biomasse-Großfeuerungsanlagen 2016. 23 p. Hamburg. 2018, http://www.infro.eu/downloads/studien/6 Holzeinsatz\%20in\%20BiomasseGro\%C3\%9Ffeuerungsanlagen\%202016.pdf (accessed 29 December 2021)

30. Pingoud, K.; Pohjola, J.; Valsta, L. Assessing the Integrated Climatic Impacts of Forestry and Wood Products. Silva Fenn. 2010, 44, doi:10.14214/sf.166.

31. Geng, A.; Yang, H.; Chen, J.; Hong, Y. Review of Carbon Storage Function of Harvested Wood Products and the Potential of Wood Substitution in Greenhouse Gas Mitigation. Forest Policy and Economics 2017, 85, 192-200, doi:10.1016/j.forpol.2017.08.007.

32. Hafner, A.; Rüter, S.; Ebert, S.; Schäfer, S.; König, H.; Cristofaro, L.; Diederichs, S.; Kleinhenz, M.; Krechel, M. Treibhausgasbilanzierung von Holzgebäuden - Umsetzung neuer Anforderungen an Ökobilanzen und Ermittlung empirischer Substitutionsfaktoren (THG-Holzbau); BMEL/BMUB: Bochum, Germany, 2017; ISBN 978-3-00-055101-7. https://literatur.thuenen.de/digbib extern/dn058600.pdf (accessed 29 December 2021)

33. Leturcq, P. GHG Displacement Factors of Harvested Wood Products: The Myth of Substitution. Sci Rep 2020, 10, 20752, doi:10.1038/s41598-020-77527-8.

34. Pingoud, K.; Ekholm, T.; Soimakallio, S.; Helin, T. Carbon Balance Indicator for Forest Bioenergy Scenarios. GCB Bioenergy 2016, 8, 171-182, doi:10.1111/gcbb.12253.

35. Valade, A.; Luyssaert, S.; Vallet, P.; Njakou Djomo, S.; Jesus Van Der Kellen, I.; Bellassen, V. Carbon Costs and Benefits of France's Biomass Energy Production Targets. Carbon Balance and Management 2018, 13, 26, doi:10.1186/s13021-018-0113-5.

36. Seppälä, J.; Heinonen, T.; Pukkala, T.; Kilpeläinen, A.; Mattila, T.; Myllyviita, T.; Asikainen, A.; Peltola, H. Effect of Increased Wood Harvesting and Utilization on Required Greenhouse Gas Displacement Factors of Wood-Based Products and Fuels. Journal of Environmental Management 2019, 247, 580-587, doi:10.1016/j.jenvman.2019.06.031.

37. Bentsen, N. Carbon Debt and Payback Time - Lost in the Forest? Renewable and Sustainable Energy Reviews 2017, 73, 1211-1217, doi:10.1016/j.rser.2017.02.004.

38. Searchinger, T.D.; Beringer, T.; Holtsmark, B.; Kammen, D.M.; Lambin, E.F.; Lucht, W.; Raven, P.; van Ypersele, J.-P. Europe's Renewable Energy Directive Poised to Harm Global Forests. Nature Communications 2018, 9, 3741, doi:10.1038/s41467-018-06175-4.

39. Hurmekoski, E.; Smyth, C.E.; Stern, T.; Verkerk, P.J.; Asada, R. Substitution Impacts of Wood Use at the Market Level: A Systematic Review. Environ. Res. Lett. 2021, 16, 123004, doi:10.1088/1748-9326/ac386f.

40. Myllyviita, T.; Soimakallio, S.; Judl, J.; Seppälä, J. Wood Substitution Potential in Greenhouse Gas Emission Reduction-Review on Current State and Application of Displacement Factors. Forest Ecosystems 2021, 8, 42, doi:10.1186/s40663-021-00326-8. 
41. IEA Bioenergy The Use of Forest Biomass for Climate Change Mitigation: Response to Statements of EASAC 2019. https://www.ieabioenergy.com/wp-content/uploads/2019/12/WoodyBiomassClimate EASACresponse Nov2019.pdf (accessed 29 December 2021)

42. Norton, M.; Baldi, A.; Buda, V.; Carli, B.; Cudlin, P.; Jones, M.B.; Korhola, A.; Michalski, R.; Novo, F.; Oszlányi, J.; et al. Serious Mismatches Continue between Science and Policy in Forest Bioenergy. GCB Bioenergy 2019, 11, 12561263, doi:https://doi.org/10.1111/gcbb.12643.

43. Camia, A.; Giuntoli, J.; Jonsson, K.; Robert, N.; Cazzaniga, N.; Jasinevičius, G.; Avitabile, V.; Grassi, G.; Barredo Cano, J.I.; Mubareka, S. The Use of Woody Biomass for Energy Production in the EU.EUR 30548 EN.; Publications Office of the European Union: Luxembourg, 2020; ISBN 978-92-76-27866-5. https:/publications.jrc.ec.europa.eu/repository/handle/JRC122719 (accessed 29 December 2021)

44. Bolte, A.; Ammer, C.; Annighöfer, P.; Bauhus, J.; Eisenhauer, D.-R.; Geisler, C.; Leder, B.; Petercord, R.; Rock, J.; Seifert, T.; et al. Fakten Zum Thema: Wälder Und Klimaschutz. AFZ - Der Wald 2021, 11/2021, 12-15. https://literatur.thuenen.de/digbib extern/dn063660.pdf (accessed 29 December 2021)

45. Wissenschaftlicher Beirat für Waldpolitik Geplante Änderung des Klimaschutzgesetzes riskiert Reduktion der potenziellen Klimaschutzbeiträge von Wald und Holz. Stellungnahme.; Wissenschaftlicher Beirat Waldpolitik beim BMEL (Hrsg.): Berlin, 2021; https://www.bmel.de/SharedDocs/Downloads/DE/ Ministerium/Beiraete/waldpolitik/klimaschutzgesetz.pdf? blob=publicationFile\&v $=5$ (accessed 28 December 2021)

46. Wissenschaftlicher Beirat für Waldpolitik Die Anpassung von Wäldern und Waldwirtschaft an den Klimawandel; Wissenschaftlicher Beirat für Waldpolitik: Berlin, 2021; ISBN 978-3-00-070408-6. https://www.bmel.de/SharedDocs/Downloads/DE/ Ministerium/Beiraete/waldpolitik/gutachten-wbwanpassung-klimawandel.pdf? blob=publicationFile\&v=2 (accessed 28 December 2021)

47. Höltermann, A.; Reise, J.; Finck, P.; Riecken, U. Forstlich ungenutzte Wälder in Deutschland. Natur und Landschaft 2020, 95, 80-87, doi:10.17433/2.2020.50153779.80-87.

48. Hennenberg, K.J.; Winter, S.; Reise, J. Die dritte Bundeswaldinventur aus Sicht des Naturschutzes. Natur und Landschaft 2017, 92, 201-208, doi:10.17433/5.2017.50153463.201-208.

49. Luick, R.; Hennenberg, K.; Leuschner, C.; Grossmann, M.; Jedicke, E.; Schoof, N.; Waldenspuhl, T. Primeval, Natural and Commercial Forests in the Context Biodiversity and Climate Protection. Part 1: Functions for Biodiversity and as Carbon Sinks and Reservoirs. Naturschutz und Landschaftsplanung 2021, 53, 12-25, doi:10.1399/NuL.2021.12.01.e. $\quad$ https://www.nul-online.de/Primeval-Forests-Natural-Forests-and-ManagedForests-in-the-Context-of-the-Biodiversity-Debate-and-ClimateProtection,QUlEPTcwMDQ4OTYmTU1EPTExMTE.html?UID=578458F2200F98A04A40433ACE61AC7F9EAED19 84F18FB (accessed 27 December 2021)

50. Devi, A.S. Influence of Trees and Associated Variables on Soil Organic Carbon: A Review. Journal of Ecology and Environment 2021, 45, 5, doi:10.1186/s41610-021-00180-3.

51. Müller, J. Die forsthydrologische Forschung im Nordostdeutschen Tiefland: Veranlassung, Methoden, Ergebnisse und Perspektiven; Univ. Rostock: Rostock, 2019; https://www.openagrar.de/receive/openagrar mods 00055651 (accessed 28 December 2021) 